Федорієнко В. А.

(0000-0002-0921-3390)

Андрощук О. В., канд. психол. наук

(0000-0002-1032-7459)

Головченко О. В.

(0000-0003-4444-0764)

Кірпічніков Ю. А., канд. техн. наук

(0000-0001-6893-3569)

Центр воєнно-стратегічних досліджень Національного університету оборони України імені Івана Черняховського, Київ

\title{
Аналіз особливостей використання спеціального програмного забезпечення оборонного планування в НАТО
}

Резюме. У статті проведено загальний аналіз спеціального програмного забезпечення оборонного планування НАТО для можливого використання у ЗС України.

Ключові слова: J-DARTS; програмне забезпечення; оборонне планування; управління оборонними ресурсами; обробка даних; IT-сервіс.

Постановка проблеми. На сьогодні у рамках співробітництва Україна-НАТО, Збройні Сили (3С) України поступово переходять на стандарти Альянсу. Це стосується різних напрямів діяльності, зокрема, організаційної структури та способів планування ресурсів. Особливостями оборонного планування в НАТО є створення чіткого алгоритму перевірки та узгодження цілей між проблемами безпеки, політичними амбіціями (потребами) та рекомендованою структурою затрачених сил. Особливості означеного алгоритму формалізовані у рамковому документі НАТО "Керівництво щодо довгострокового оборонного планування" (Handbook on Long Term Defence Planing, SAS-025), який входить до серії SAS - System Analysis and Studies Panel), яка містить теоретичні основи системного аналізу та предметні дослідження у термінології НАТО. У цьому керівництві проблеми безпеки представлені різними типовими задачами, у вигляді сценаріїв, під які надаються конкретні вимоги. Процес визначення найкращого варіанта структурних елементів ЗС країнчленів НАТО проводиться за вибором на основі критеріїв вартості та ефективності. Ці вимоги представлені певними спроможностями, які узгоджуються 3 можливостями структурних елементів 3С.

Нині відомі різні програмні засоби для ведення оборонного планування країн-членів HATO, але найбільш поширеним і таким, що відповідає вимогам керівництва SAS-025 визнане спеціальне програмне забезпечення (СПЗ) J-DARTS (Joint Defence Planning Analytical Requirement Toolset Інструментарій для формування аналітичного запиту об'єднаного оборонного планування). Це СПЗ описує процес, який базується на спроможностях і сценаріях, типових для оборонного планування. Такий набір інструментів надає виконавцям довгострокового оборонного планування систематичний підхід до створення зв'язків із запитами безпеки на вищому рівні та механізми для впровадження рекомендацій щодо удосконалення структури, зокрема із врахуванням невизначеності майбутнього. Завдання цього підходу оборонного планування полягає у допомозі керівникам щодо визначення пріоритетів між економічними обмеженнями та готовністю ЗС (для країн НАТО - національною готовністю та міжнародними зобов'язаннями).

У статті проведено загальний аналіз спеціального програмного забезпечення оборонного планування, зокрема J-DARTS. Аналізу підлягали проблемні питання впровадження програмного забезпечення (ПЗ) для оборонного планування ЗС України, звіти кращих практик експлуатації J-DARTS $[1,2]$ i рекомендації експертів НАТО, наданих під час заходів за сприяння Трастового фонду НАТО 3 допомоги Україні в удосконаленні національної системи управління [3].

Аналіз основних досліджень i публікацій. Питання щодо розроблення моделей, методів і методик для оборонного планування у ЗС України були досліджені у роботах таких українських вчених, як В. Шевченко, Р. Тимошенко, М. Лобко, В. Биченков [4-7] та ін. У роботі [8] розглядається низка питань, пов'язаних із функцією планування місій, та огляд методів, засобів і процедур, які використовуються країнами-членами НАТО для військових систем оборонного планування та планування місій, зокрема систем, призначених для підтримання родів військ військово- 
повітряних сил, об’єднаних сил і військовоморських сил Канади та США.

Проблеми аналітичної підтримки трансформації і довгострокового планування в оборонній сфері та досвід використання програмного забезпечення J-DARTS y Королівстві Норвегія викладені в [9, 10]. Аналіз програмного забезпечення J-DARTS та його можливості використання для 3С України наведені у роботі [3].

Метою статті $\epsilon$ проведення аналізу спеціального програмного забезпеченням оборонного планування НАТО для надання обгрунтованих рекомендацій щодо можливості його використання у ЗС України.

Виклад основного матеріалу. На виконання стратегічної цілі 1 Стратегічного оборонного бюлетеня України [11], було поставлено завдання створення базових основ єдиної інформаційної системи управління оборонними ресурсами (DRMIS) та відповідної інфраструктури, складовою якої $\epsilon$ інформаційна система управління оборонним плануванням на основі спроможностей (Capability-Based Defense Planning, CDP). Відповідно було сформовано вимоги до запровадження процесу оборонного планування на основі спроможностей CDP i підвищення рівня оперативної сумісності 3С України та інших військових формувань 3 підрозділами збройних сил держав-членів НАТО та ЄС для виконання спільних завдань у міжнародних операціях із підтримання миру i безпеки.

Очевидно, що інформаційна підтримка управлінських рішень стратегічного планування може виконуватись лише за допомогою сучасних комп'ютерних інформаційно-аналітичних систем (IAC), які мають виконувати функції [4]: обгрунтування прийнятих рішень; знаходження оптимального рішення моделювання та прогнозування розвитку об'єктів управління; знаходження в ієрархічній структурі слабких місць 3 метою усунення та вдалих рішень для розповсюдження позитивного досвіду; знаходження сукупностей подібних рішень 3 метою узагальнення, виявлення закономірностей, синергетичних властивостей тощо.

Досвід України показує, що впровадження СПЗ оборонного планування за підтримки НАТО для потреб 3С України було розпочато у другій половині 1990-х років.

$\underline{D R M} . \quad$ Однією 3 перших IAC оборонного планування в Україні (1996 - 2003 рр.), була американська модель управління оборонними ресурсами (Defense Resources Management Model, DRMM) [5] (замовник Пентагон, наукове супроводження корпорація РЕНД), яка за допомогою модулів структури сил i вартості оцінювала та прогнозувала видатки збройних сил. Оцінювання ефекту виконувалось за допомогою лінійної моделі бойових потенціалів Taskform. Недоліками DRMM були складність підготовки та введення вхідних даних, низька адекватність моделі ефектів, неможливість розв'язання оптимізаційних задач, непристосованість до українського законодавства, суттєві проблеми щодо модифікації та усунення недоліків $[5,12]$.

IAC “Pесурс". У 2003-2006 роках в Україні була розроблена IAC підтримки оборонного планування "Ресурс" (замовник ЗС України, розробник - НДІ АКС Екотех; прийнята на озброєння та введена в експлуатацію в ЗС України наказом Міністра оборони України від 22.08.2006 № 498). Це був перший крок до узгодженості дій у реформуванні армії та складанні оборонного бюджету. Запровадження цієї системи було передбачено, зокрема, Цільовим планом Україна-НАТО на 2006 рік.

За допомогою IAC "Ресурc" було створено унікальний інформаційний ресурс за формулярами всіх військових частин у розрізі ix особового складу, утримання основних фондів, забезпеченості матеріальними ресурсами, озброєння та військової техніки. Це забезпечило можливості моделювання альтернативних структур 3C, визначення витрат на проведення заходів з реформування та інших оборонних витрат. Завдяки IAC "Ресурс" удалося відпрацювати технологію збору інформації щодо стану ресурсів i закласти основи обгрунтування бюджетних інтересів 3С України. IAC "Ресурс" дала змогу обраховувати не тільки потребу, але й очікувані терміни виконання програм. Варто додати, що найбільш відомим у світі аналогом IAC "Ресурс" є система, яка розроблена та встановлена на замовлення оборонного відомства США і використовується в більшості країн-членів НАТО. Застосування інформаційно-аналітичної системи "Ресурс" дало змогу заощаджувати від 20 до $30 \%$ витрат порівняно $з$ початковими планами.

ЕСУ АГП ЗС Украӥни. До кроків модернізації доречно віднести наказ Міністерства оборони України від 17.01.2006 № $12074 / 3,3$ якого почалось розроблення Єдиної системи управління адміністративно- 
господарськими процесами 3С України [13]. У дослідному зразку цієї системи реалізовано функціонал, який було закладено у тестовий зразок підсистеми “Рішення" Єдиної системи управління адміністративно-господарськими процесами ЗС України (ЕСУ АГП 3С України) у 2006-2010 pp. Вiн реалізований на програмній платформі ERPсистеми (Enterprise Resource Planning планування ресурсів підприємства) компанії SAP AG (Німеччина), а саме за допомогою інструментів інтеграційного функціонального модулю SAP Defense Public and Security (SAP DFPS) [14, 15]. Відомо, що цей модуль було розроблено за стандартами НАТО і перебуває на озброєнні у передових країнах-членах Альянсу. За функціональними можливостями ЄСУ АГП ЗС України перекриває IAC "Ресурс" [13,16], та, відповідно, ці дві системи взаємно інтегрується. Проте через обмеженість прав на користування під час промислової експлуатації П3 SAP, зокрема, через відсутність достатньої кількості ліцензій SAP (модуль DFPS), часткового прийняття на озброєння лише окремих підсистем, призупинення розроблення проєкту у 2008-2010 рр., тому ЄСУ АГП ЗС України повною мірою реалізована не була.

Планування сил на основі спроможностей. Наразі створення модернізованої інформаційної системи (IC) оборонного планування передбачено
Стратегічним оборонним бюлетенем України та іншими керівними документами у складі IC управління оборонними ресурсами (Defense Resources Management Information System, DRMIS). Відповідно у Міністерстві оборони (MO) України та Генеральному штабі (ГШ) ЗС України здійснюються заходи щодо переходу на оборонне планування на основі спроможностей у рамках програми переходу України до стандартів НАТО. Майбутнє оборонне планування бачиться, як дві складові [17]:

планування сил на основі спроможностей під час оборонного огляду 3 визначенням обрису сил оборони;

оцінювання окремих спроможностей за ï базовими складовими, забезпечення розвитку існуючих спроможностей.

На рис. 1 наведена модель процесу i основних компонентів довгострокового планування (20-30 років), яка прийнята за основу в НАТО, і розглядається як прототип для ЗС України. Як видно 3 рис. 1, є два основних напрями аналізу:

аналіз військової структури, метою якого є визначення спроможностей і витрат на поточну і майбутню структуру сил;

аналіз сценаріїв - розробляються вимоги до спроможностей на основі інтерпретації середовища безпеки, майбутніх викликів i національних стратегічних цілей [1].

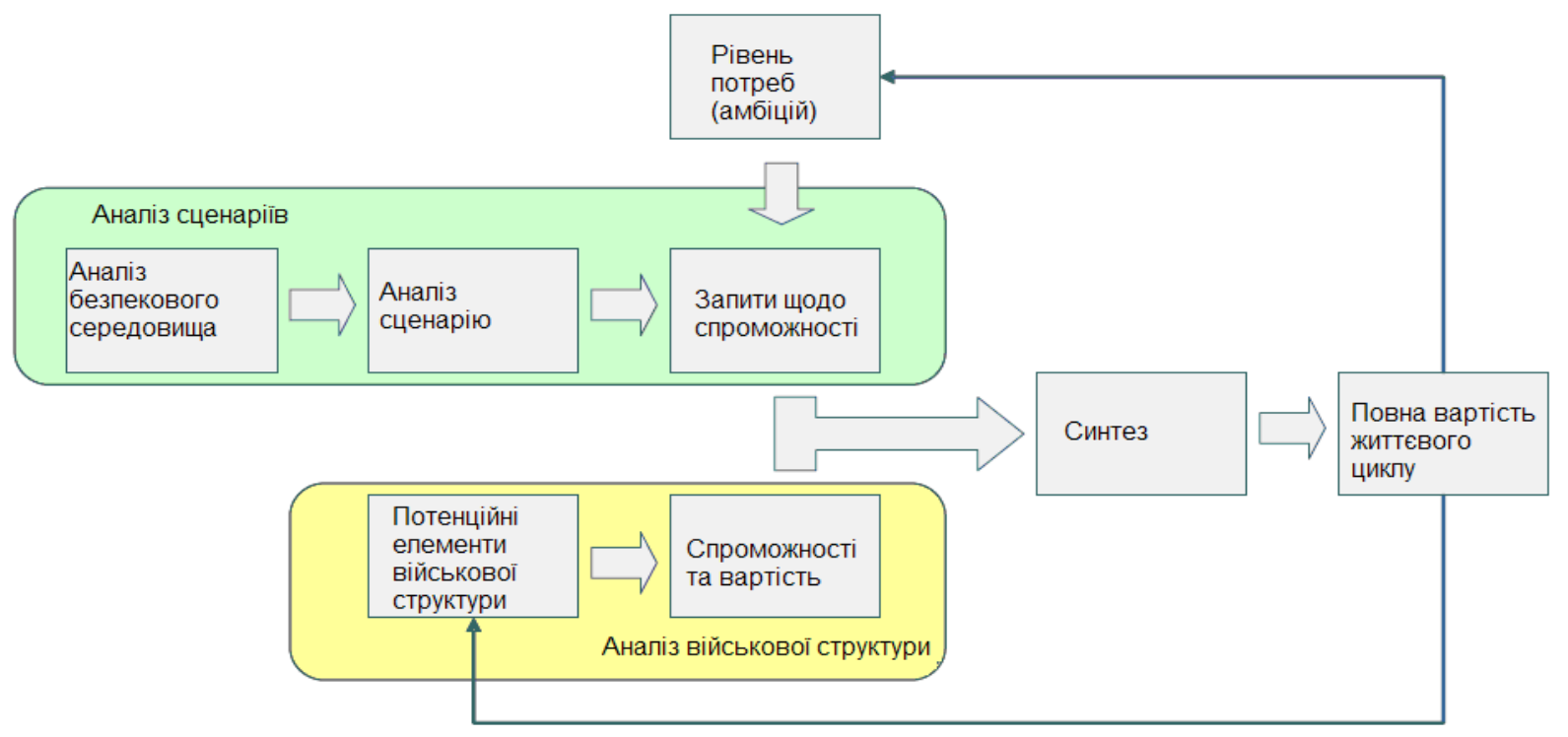

Рис. 1. Схема процесу довгострокового планування в НАТО

$\begin{array}{cccr}\text { У } & \text { роботі [8] } & \text { була запропонована } \\ \text { таксономія } & \text { для } & \text { визначення }\end{array}$ найпоширеніших систем планування в країнах НАТО, та зазначено, що деякі системи планування, засновані на теорії штучного інтелекту покладаються на методи перепланування для розроблення так званих "обдуманих" планів. Таке спеціальне програмне забезпечення (СПЗ) для підтримки процесу планування, є надшвидким за своєю 
суттю, що створює плани, а потім модифікує їх на основі несподіваних подій або ситуацій. Підходи 3 функцією перепланування використовувались під час розроблення багатьох військових систем планування НАТО [18], зокрема, DART (інструмент динамічного аналізу та перепланування), TARGET (аналіз на рівні театру воєнних дії із графічним представленням), Cypress-SIPE2 (планування та реагування в невизначених і динамічних середовищах) та ін.

Отже узагальнена класифікація систем планування для спільних операцій НАТО [8] включає:

1. Системи планування для операційного розгортання та для підтримки ведення операції (як модуль, у складі бойових систем управління). Серед них:

FOX Генетичний алгоритм (FOX Genetic Algorithm, FOX-GA) - для генерації та оцінювання планів у складній області планування військових маневрів;

автоматизована система планування театру воєнних дій для контингенту (Contingency Theater Automated Planning System, CTAPS);

спільний асистент для розроблення та виконання планів (Joint Assistant for Development and Execution, JADE);

інструмент динамічного аналізу та перепланування (Dynamic Analysis and Replanning Tool, DART);

система підтримки передбачуваного планування (Anticipatory Planning Support System, APSS);

редактор даних для розгортання військ за часовими фазами (Time-Phased Force Deployment Data Editor, TPEDIT);

спільна система оперативного планування (Collaborative Operational Planning System, COPlanS).

2. Інші специфічні системи військового планування, які також поширені у країнах НАТО, це:

рочестерська система інтерактивного планування (The Rochester Interactive Planner System, TRIPS);

сегмент планування та виконання кризових дій шляхом обговорювання (Deliberate Crisis Action Planning and Execution Segment, DCAPES);

планування спільних дій у кризі на морі

(Joint Maritime Crisis Action Planning, JMCAP); система об'єднаного стратегічного планування (Joint Strategic Planning System JSPS); apхітектура відкритого планування (Open Planning Architecture, O-Plan).

Підходи на основі логіки та ієрархічної мережі завдань (Logic-based and hierarchical task network), також були запропоновані в ранніх i сучасних системах планування та залишаються досить популярними.

Інший метод, заснований на штучному інтелекті, а саме на програмуванні обмежень [19], також був предметом дослідження під час розроблення СПЗ для систем планування в США та Канаді. Інші інформаційні технології, як-от глибинний аналіз даних - Data Mining (використовується для вилучення прихованої інформації 3 баз даних); управління знаннями - knowledge management; онлайн аналітична обробка даних - online analytical processing (спосіб представлення реляційних даних користувачам); інструменти бізнесаналітики - business intelligence tools, широко використовуються під час розроблення сучасних систем військового планування.

$\underline{D A R T}$. І Із перерахованих систем, для вирішення задач у рамках національного оборонного планування широкого застосування у країнах НАТО набула модель динамічного аналізу та перепланування DART. Це інтерактивна інформаційна система, яка допомагає військовим відповідальним за планування під час розроблення та аналізу військових планів (планів оборони) для розміщення значної кількості військ i техніки. Кожен план розгортання визначається структурою даних, яку називають “Даними про сили та розгортання за часом" (Time Phased Force and Deployment Data, TPFDD). Вона описує вимоги до руху військ і техніки [8]. DART $€$ частиною набору автоматизованих засобів обробки даних і системи управління базами даних, призначених для швидкого створення, перегляду та редагування TPFDD, а також для аналізу транспортних можливостей реалізованих у плані. Як результат, DART дає змогу планувальникам модифікувати TPFDD i встановлювати та запускати стратегічні моделі транспортування протягом декількох хвилин. Отже, використання DART дає змогу розглянути більше альтернатив i створити за менший час потенційно здійсненний курс дій.

J-DARTS. Наслідуваність технологій моделі DART можна спостерігати у більш сучасному програмному продукті J-DARTS. Це комплексний програмний інструмент для планування і аналізу оборонного планування у HATO. J-DARTS представлена 
інформаційною системою (IC) оборонного планування на основі оборонних спроможностей. Розробником продукту JDARTS виступає агентство HATO 3 консультацій, командування і управління (NATO Consultation, Command and Control Agency, NC3A). 32001 року NC3A підтримує J-DARTS, контролює i управляє конфігурацією інформаційна система (IC), поширює доступ країнам НАТО [1].

Функціональна побудова IC J-DARTS на основі процесів планування в НАТО призначена для підтримки кожного 3 кроків процесу довгострокового планування в НАТО, для спрощення переходу від одного виду діяльності до іншого. Це досягається за допомогою низки багатокористувацьких додатків, пов'язаних між собою, які працюють 3 базами даних в CDR (Central Data Repository) і зберігаються в Центральному сховищі даних (група серверів SQL Server).

Iз перелічених систем за своїм функціональним призначенням та наповненням система J-DARTS найбільш повно відповідає задачам оборонного планування на національному рівні. Отже розглянемо іii функціональність більш детально. DARTS $€$ :

Основними додатками у наборі J-

D-MIST (Defense Planning Mission Study Tool) - інструмент дослідження процесу оборонного планування для місій - додаток, який підтримує аналіз сценаріїв, включаючи ієрархічну декомпозицію задачі та створення, зберігання та візуалізацію окремих сценаріїв $і$ описів сценаріїв.

D-CALC (Defense Planning Capability Assignment Logical Calculator) - калькулятор логіки призначення можливостей військового планування - підтримує як аналіз місії за допомогою розроблення (незалежних від сценарію) правил щодо розподілу спроможностей, так і аналізу місій шляхом застосування цих правил за конкретними сценаріями.

D-SIGN (Defense Planning Scenario Information and Geographical analysis) інструмент інформації та географічного аналізу сценаріїв планування оборони. Використовуючи інтерфейс GIS, роль D-SIGN полягає в тому, щоб задавати сценарії відповідно до структури, заданої аналізом місії, i, таким чином, надавати значення параметрів для логіки розподілу спроможностей.
D-RUM (Defense Planning Requirement and Unit Matching) - інструмент планування оборонних вимог і зіставлення підрозділів: 3 одного боку, сховище для реальних організаційних одиниць (підрозділів) i ïx спроможностей, 3 іншого - інструмент для агрегації вимог до спроможностей, що випливають 3 (комбінацій) сценаріїв. D-RUM також $\epsilon$ керуючим інтерфейсом до D-EFT (див. нижче) i сховищем для остаточного зосередження сил, що виникає внаслідок роботи D-EFT.

D-EFT (Defense Planning Extended Fulfillment Tool) - інструмент розширеного військового планування) - використовуються підходи оптимізації для знаходження мінімального набору сил (за критерієм вартості), який задовольняе всім вимогам щодо спроможностей у разі дотримання набору обмеження на використання одиниць, зосередження сил тощо [9].

Візуалізація структури J-DARTS. Для встановлення відповідності вимогам структури сил, використовують вбудовані інструменти відображення елементів структури та категорії спроможностей.

Особливості впровадження J-DARTS. Загальна структура сил може не бути повністю визначена після першої ітерації у JDARTS. Необхідно визначити шлях від поточної структури до цільової структури, проаналізувати загальну вартість як основної структури сил, так i допоміжної, оцінити ризик, пов'язаний із придбанням зразків новітніх технологій, ввести конкретні обмеження i керівні вказівки. Для цього, рекомендується проводити низку ітерацій, під час яких може виявитися, що рівень потреб має бути скоректований. Наприклад, загальна вартість реалізації початкових значень потреб може виявитися занадто високою [2]. HATO:

Приклади використання J-DARTS у

J-DARTS використовується як інструмент огляду (оцінки) вимог щодо потенціалу НАTO (Capability Requirements Review, CRR) та підтримки CRR у цілому;

J-DARTS застосовується Міністерством оборони Королівства Норвегія для підтримання норвезького довгострокового оборонного планування у Норвезькому науково-дослідному центрі оборони (FFI), (починаючи 3 Оборонного дослідження 2007 року).

J-DARTS було застосоване у низці напрямів забезпечення основи процесу структурування збройних сил країн НАТО [1, 
10]. На сьогодні це один 3 основних інструментів Північноатлантичного альянсу, який полягає в основі нового безперервного процесу планування.

Висновки. Отже, у роботі було проведено загальний аналіз інформаційних систем планування у військовій сфері та визначено особливості використання спеціального програмного забезпеченням оборонного планування НАТО для можливого використання у ЗС України. Аналіз грунтувався на основі дослідження міжнародного досвіду розроблення та експлуатації систем оборонного планування та планування місій, що відповідають конкретним військовим потребам. Огляд охопив загальні питання, пов'язані з функцією планування, методами, інструментами та процедурами планування у складних військових системах. Також було розглянуто нові методи, задіяні у проєктуванні вдосконалених систем планування.

Основними проблемними питаннями впровадження оборонного планування на основі спроможностей вбачається недостатня розвиненість нормативної (доктринальної) бази, недостатнє усвідомлення відповідних процесів і відсутність інструментів інформаційно-аналітичної підтримки оборонного планування 3С України.

Використовуючи IC J-DARTS можна наблизитися до моделі структури оборони країн НАТО у контексті оборонного планування на основі спроможностей. JDARTS. Це СП3 - складний набір інструментів, який забезпечує гнучкість i модульність для підготовки та проведення повного аналізу в рамках оборонного планування, може потребувати значних витрат часу i робочих ресурсів на етапі впровадження. Під час використання JDARTS може стати сховищем даних i метаданих, що спростить і прискорить процес планування, наприклад, завдяки використанню необхідних шаблонів аналізу сценаріїв (варіантів) планування.

У подальшому доцільно визначити основні відмінності принципів системи планування 3С України відповідно до вбудованих механізмів в IC J-DARTS.

\section{СПИСОК ВИКОРИСТАНОЇ ЛІТЕРАТУРИ}

1 NATO Defence Planning Capability Review 2017/2018. NATO Documents. 2018. URL: https://www.fmn.dk/temaer/nato/Documents/NATODefence-Capability-Review-2017-2018-DenmarkOverview.pdf.
2. Shahbazian E. Requirements for the GCCS-M Replacement based on Land Forces Systems [Електронний ресурс] / Elisa Shahbazian // Defence Research and Development Canada. 2015. URL: http://cradpdf.drdc-rddc.gc.ca/PDFS/unc200/ p801735_A1b.pdf.

3. Сиротенко А. М., Степанюк М. Ю. Інформаційна система управління оборонним плануванням на основі спроможностей J-DARTS i можливості іiі впровадження у Збройних Силах. Наука $i$ $\begin{array}{llll}\text { оборона. 2018. № 4. } & \text { C. 29-34. DOI: }\end{array}$ https://doi.org/10.33099/2618-1614-2018-5-4-29-34.

4. Шевченко В. Л. Оптимізаційне моделювання в стратегічному плануванні. Київ : НУОУ, 2011. $283 \mathrm{c}$.

5. Комп'ютерна модель управління оборонними ресурсами "DRMM": сучасний стан та перспективи розвитку : монографія / В. Л. Шевченко та ін. ; за ред. В. Л. Шевченко. Київ : ННДЦ ОТ і ВБ, 2004. 218 с.

6. Тимошенко Р. I., Лобко М. М. Проблеми вдосконалення планування оборони України. Наука і оборона. 2018. № 1. C. 11-17. URL: http://nbuv.gov.ua/UJRN/nauio_2018_1_4.

7. Биченков В. В. Синтез системи підтримки прийняття рішень визначення рівня спроможностей Збройних Сил України в ході оборонного планування. Сучасні інформаційні технології у сфері безпеки та оборони. Київ, 2015. № 3. C. 9-17.

8. Survey of Military Planning / A. Guitouni, A. Boukhtouta, A. Bedrouni та ін. // Defence Research and Development Canada. 2011. URL: https://www.researchgate.net/publication/228437196 _AGuitouni_A_survey_of_military_planning_syste ms.

9. Glærum S., Hennum A. Analytical Support to Defence Transformation. Norwegian Defence Research Establishment. 2010. URL: https://pdfs.semanticscholar.org/21f0/39f8c758ce954 3dd6238e6932dd7d69b6a12.pdf.

10. Sigurd G., Hennum A. Analytical Support to Norwegian Long-Term Defence Planning. Mimořádné číslo. 2016. № 25. C. 78-87.

11. Про рішення Ради національної безпеки i оборони України від 20 травня 2016 року "Про Стратегічний оборонний бюлетень України” : Указ Президента України від 06.06.2016 р. № 240/2016. URL: https://www.president.gov.ua/ documents/2402016-20137 (дата звернення: 25.04.2020).

12. Облік оборонних ресурсів за допомогою формуляра військової частини. Частина 1. Методики опрацювання формуляра : монографія / В. Л. Шевченко та ін. ; за ред. С. Ф. Шелеста, В. Л. Шевченка. Київ : ННДЦ ОТ і ВБ України, ГШ ЗС України, 2003. 160 с.

13. Сініцин І. П., Сироватський Л. А., Милашенко Ю. І. Особливості автоматизації процесів первинного обліку наявних ресурсів військових частин Збройних Сил України. Збірник наукових праць Центру воєнно- 
стратегічних досліджень Національного університету оборони України імені Івана Черняховського. Київ, 2013. № 1. С. 73-76.

14. Escherich B, Pfriemer H., Ullwer W. SAP for DFPS - Implementierung und Customizing. Bonn : SAP press, 2010. 664 c.

15. Андерсон Д., Ларокка Д. SAP за 24 часа / пер. с англ. В. М. Котовский. Днепропетровск : Баланс Бизнесс Букс, 2007. 400 с.

16. Педан Ф. П., Руденська Г. В., Ткаченко М. В., Федоренко Р. М. Порівняльний аналіз інформаційних систем автоматизації процесів управління фінансово-економічною діяльністю. Збірник наукових прачь Центру воєнностратегічних досліджень Начіонального університету оборони України імені Івана Черняховського. Київ, 2016. № 2. С. 95-100. 17. Степанюк М. Ю., Юрчина Ю. В. Проблеми переходу до планування на основі спроможностей. URL: http://defpol.org.ua/ index.php/produkty-tsentru/aleia-heroiv/448problemy-perekhodu-do-planuvannia-na-osnovispromozhnostei.

18. Wilkins D., Myers K., Lowrance J. Planning and Reacting in Uncertain and Dynamic Environments. Journal of Experimental and Theoretical Artificial Intelligence. 1995. № 7. C. 197-227.

19. Zweben M., Fox M. S. Intelligent Scheduling. San Francisco: Morgan Kaufmann, 1994. 709 c.

Стаття надійшла до редакційної колегії 27.06.2019

\section{Analysis of the use of the special software for defense planning in NATO}

\section{Annotation}

The paper reviews the state and retrospective analysis of special software used to support defense planning processes in the Armed Forces of Ukraine, namely: the Defense Resources Management Model (DRMM) and the subsystem of the Unified Management System for Administrative and Economic Processes of the Armed Forces of Ukraine based on the SAP ERP software platform.

The paper reviews the state and retrospective analysis of special software used to support defense planning processes in the Armed Forces of Ukraine, namely: the Defense Resources Management Model (DRMM) and the subsystem of the Unified Management System for Administrative and Economic Processes of the Armed Forces of Ukraine based on the SAP ERP software platform. In accordance with the provisions of the Strategic Defense Bulletin, the Armed Forces of Ukraine are moving to capabilitybased defense planning. This type of planning is a standard type for NATO countries. The NATO planning structure outlined in the paper is a prototype for the future planning of the Armed Forces of Ukraine. There is a need for defense planning software tools that meet the requirements of interoperability with NATO defense planning systems. To this end, a general analysis of the special software of NATO's military planning systems was conducted during the study.

The authors of the article have identified the main trends in the construction of modern foreign military planning systems. Classification of planning systems according to their purpose, which is common for NATO countries, was carried out. These technologies not only include the Dynamic Analysis and Rescheduling Tool (DART) and the Joint Defense Planning Analytical Request Toolkit (JDARTS) but also in terms of its functional purpose and content, best meets the tasks of defense planning at the national level. Therefore, a comprehensive software tool for planning and analyzing defense planning in NATO has been explored in more detail. Given the broad functionality of J-DARTS, this tool is proposed to be considered to test the needs of defense planning in the Armed Forces of Ukraine.

Keywords: J-DARTS; Software; Defense Planning; Defense Resource Management Model; DRMM; Data Processing; IT service. 